\title{
THE ECONOMIC FALLOUT OF EXCLUSION OF THE ISLAMIC REPUBLIC OF IRAN FROM THE SWIFT INTERNATIONAL PAYMENT NETWORK
}

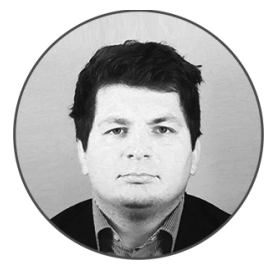

Article history:

Received 23 January 2018 Received in revised form 7 February 2018 Accepted 22 February 2018 Translated 16 July 2018 Available online 28 September 2018

JEL classification: F40, F51, G21, P45

Keywords: sanctions, banking system, payment system, blockchain

\author{
Kamal A. OMAROV \\ Diplomatic Academy of Ministry of Foreign Affairs of Russian Federation, Moscow, Russian Federation \\ omarov.k.a@yandex.ru \\ https://orcid.org/0000-0002-4984-367X
}

\begin{abstract}
Importance Sanctions, which the USA and EU imposed on Iran in 2012, shattered the economic situation in the Islamic Republic of Iran. Restrictions affected not only the Central Bank of the Islamic Republic of Iran and dozens of national commercial banks but also the SWIFT network as the most crucial mechanism of global financial transactions. The article reviews the economic fallout of Iran's disconnection from the SWIFT global payment network.

Objectives The research seeks an alternative method for cross-bank settlements, which would make Iran independent from the SWIFT network.

Methods The research relies upon statistical, comparative and logic methods.

Results The sanctions against the Islamic Republic of Iran undermines GDP and export of goods, fueled the inflation nationwide and devaluation of the national currency. They also brought more than a half of the Iranian enterprises on the brink of crisis.

Conclusions and Relevance If the Central Bank of Russia modernizes and promotes its financial messaging system, it may turn up a competitive product in the global market of payment processing systems. The combination of the blockchain technology and the Russian developments may attract foreign financial institutions to seek cooperation in banking, lure new customers worldwide and in those environments, which are exposed to the risk of being disconnected from the widely spread and monopolistic payment network.
\end{abstract}

๑) Publishing house FINANCE and CREDIT, 2018

The editor-in-charge of this article was Irina M. Vechkanova

Authorized translation by Irina M. Vechkanova

January 1, 2012, the U.S. Federal Government imposed sanctions against the Central Bank of the Islamic Republic of Iran. January 23, 2012, the European Union countries gradually slow down their cooperation with the oil sector of the Islamic Republic of Iran and its Central Bank. From January to February, the United States Department of the Treasury placed restrictions on Iran's Tejarat Bank and Dubai-based Noor Islamic Bank as the USA

${ }^{\dagger}$ For the source article, please refer to: Омаров К.А. Экономические последствия отключения Исламской Республики Иран от международной платежной системы SWIFT. Финансы и кредит. 2018. T. 24. № 3. C. 722-736. URL: https://doi.org/10.24891/fc.24.3.722 spotted the assistance it provided to Iran in evading international sanctions. In March 2012, the SWIFT network put a halt to servicing Iran's financial institutions, which were subject to the EU sanctions ${ }^{1}$. In 2012 three packages of sanctions were taken into effect. As part of the first sanctions package, the Iranian banks were cut off from the SWIFT network. In fact, it isolated the Iranian banks from the rest of the world making the national financial

\footnotetext{
${ }^{1}$ Yashlavskii A. [Will Russia be cut off from SWIFT like Iran?]. Moskovskii komsomolets, 2015, January 28.

URL: http://www.mk.ru/economics/2015/01/28/otklyuchat-li-rossiyu-otswift-kak-eto-bylo-s-iranom.html (In Russ.)
} 
institutions look at less effective, costly and legally dubious schemes for international trade and currency deals, primarily, in the oil sector. The second package prohibited the insurance coverage for oil tankers transporting the Iranian hydrocarbons. Finally, the third package marked the beginning of the EU embargo on purchase of the Iranian oil [1]. In this article I solely discuss the disconnection of the Iranian banks from SWIFT and further propose my own solutions, which may be effectuated with the help and for the interests of the Russian Federation. The above measures of the Western countries are a fairly reasonable response to the nuclear program of Iran. It is noteworthy that the Iranian government presided by Mahmoud Ahmadinejad accelerated the nuclear program development, thus agitating the global community and invoking new sanctions against Iran. The restrictions are certain to have undermined the economic development of Iran, while the exclusion of the Iranian banks from the SWIFT network weakened the foreign trade of Iran.

It is important to understand what the SWIFT payment network looks like. Being developed by the global community, the SWIFT payment network is a leading international system of financial communications transporting financial messages in a prompt, secure and reliable manner worldwide.

The SWIFT community was created in 1973 by 239 banks and 15 countries in accordance with the Belgian laws [2]. The number of its users has grown more than 40 times, embracing nowadays about 10 thousand financial companies in 200 various States [3]. The SWIFT network is an absolute leader among the existing international payment processing systems. It transfers over one million transactions, which amount to over 2.5 billion annually ${ }^{2}$. Furthermore, according to some sources of the National Security Agency of the United States of America has access to information about all transactions passing within the system ${ }^{3}$.

\footnotetext{
${ }^{2}$ Mezhdunarodnye denezhnye perevody po sisteme SWIFT [International money transfers through the SWIFT network]. URL: http://biznesdelo.ru/denezhnye-perevody/denezhnye-perevody-svift.html (In Russ.)

${ }^{3}$ SA Spies on International Payments.

URL: http://www.spiegel.de/international/world/spiegel-exclusive-nsaspies-on-international-bank-transactions-a-922276
}

What mainly affects the development of the Russian Iranian economic relationship is a lack of effective mechanisms for banking and financial activities as part of foreign trade. Both parties certainly maintain a continuous dialogue to improve respective activities and even settle their accounts in national currencies. However, the cooperation between Russia and Iran stalled due to the Western sanctions against the latter [4]. In my opinion, the economic cooperation between Russia and Iran suffered the most painful blow when the Central Bank of Iran was kicked off the network and Iranian banking institutions were excluded from the SWIFT network. The sanctions were not long standing. In 2016, the Iranian government headed by Hassan Rouhani succeeded in defying most of the economic sanctions and had access to the international interbank system resumed [5]. However, I believe, the Iranian economy was teetering on the brink of abyss during the period. For example, GDP decreased by USD 75.5 billion during the first year of the sanctions, while the export of goods fell by USD 21.5 billion against a 12.5-percent increase in inflation ${ }^{4}$. I also should mention that the disconnection from SWIFT inflicted the devaluation of currency [6]. Over six thousand production enterprises (about 67 percent of their total number) were almost bankrupt [7] (Fig. 1).

Iran's economic losses could cause more detrimental fallouts if the business community of Iran did not expect such sanctions and adapted to respective measures. Iran made active attempts to bypass the barriers trying alternative methods of interbank payments. For instance, numerous settlements in national currencies, barter deals, usage of gold in trade, exchange of third county's currency, Hawala money transfers and U-turn transactions. Paragraphs below overview all the main methods of trade deals, which Iran resorted to, when trying to bypass the sanctions against its banking sector.

It got much more complicated to settle international deals with the U.S. dollars due to the measures against Iran. In 2012-2013 Iran had at least three

\footnotetext{
${ }^{4}$ DataBank. World Development Indicators. URL: http://databank.worldbank.org/data/reports.aspx?source=WorldDevelopment-Indicators
} 
foreign exchange rates - the official rate of the Central Bank, convertible rate for import and export purposes and free rate (market). Therefore, if the client had a deposit in the U.S. dollar with the Iranian bank, the bank did not extend them to the client, but rather was ready to buy them at its official rate. Such conversion entailed certain losses for the client. Moreover, if the currency was needed for some individual purposes, the U.S. dollar could be bought in the free market at triple price [8]. Thus responding to the sanctions, Iran had to transact using only national currencies. Iran agreed with India, China and Turkey to use rupee, yuan and lira respectively for payments. Using the national currencies of the above countries, Iran purchased local goods.

Hydrocarbons are the main products which Iran exchanged for goods or money. In 2015, Russia and Iran made barter arrangements obliging Iran to supply oil to Russia, while Russia was to deliver construction materials, equipment and grain crops. Such deals were also clinched with India and China. For example, India undertook to supply rice, pharmaceuticals and steel in exchange for the Iranian oil ${ }^{5}$.

Being laden with the sanctions, Iran did not disdain to accept gold as a means of payment. This can be illustrated with the Turkish-Iranian deal for exchange of gas for gold. There a 37-fold increase in the imported goal from Turkey was recorded. However, the deal enabled the USA and EU to exert much political pressure on Turkey, thus forbidding to sell gold and other precious metals in Iran [9].

If Iran faced any difficulties in settling deals with national currencies, it could obtain the U.S. dollar by simply exchanging the Iranian rial for the U.S. dollar in other countries. In September 2012, there were more instances of exchange of the Iranian rial for the U.S. dollar in Afghanistan. The Afghan intermediaries were found to exchange a given amount and transfer money to Iran using, indeed, rather a trivial method, i.e. Iranian taxis running across the Iranian Afghan border and Herāt.

\footnotetext{
${ }^{5}$ [Iran lures oil buyers with low prices]. Vedomosti, 2012, August 8. URL: https://www.vedomosti.ru/finance/articles/2012/08/08/iran_zaman ivaet_pokupatelej_nefti_nizkimi_cenami (In Russ.)
}

The Hawala payment transfer system is interesting as well. The Hawala system is distinctive as all financial transactions are not supported with documents, but rather rest upon the confidence of parties. Brokers of the Hawala system are the main actors in the scheme since they arrange crosscountry transfers of money. Money physically remains in the country since the remitter channels money to the broker in the same country. It receives a secret code, which generally consists of digits indicated on one of the banknotes, while the beneficiary in the other country shall produce this code only to a second broker in order to obtain the equivalent amount in the local currency. As a result, brokers settled their accounts through a clearance system, which may involve gold, precious metal and services in certain cases in order to close off the balance. The Hawala system does not entail numerous bureaucratic technicalities, having the maximum threshold for money transfer (usually up to USD 100 thousand) and channeling the transfer within 48 hours. The Hawala systems charge rather low fees for transactions, ranging from 1 to 1.5 percent of the transferred amount. Such characteristics enables brokers to remain inconspicuous for the U.S. regulator, which monitored whether the anti-Iran sanctions are observed, and countered money laundering practices. The Hawala system could wire money from Iran to a certain country of the Middle East and then stream it to various banks of Asia, Europe and the USA ${ }^{6}$. Confidentiality of the Hawala system is another merit, making it attractive, though vulnerable to abuses [10].

The U-turn cooperation between the Iranian and European banks became one of the most popular schemes in Iran during the sanctions. I should note that the USA qualified such transactions as money laundering. The $U$-turn scheme is designed so that the customer purchases the oil from the Iranian party for its national currency. Payment is debited to the bank account located outside Iran. Afterwards it was wired to a U.S. bank account. There money is converted into the U.S. dollars and subsequently

\footnotetext{
${ }^{6}$ Reshchikov O. [Iran: Countering the Western sanctions in banking]. Novoe Vostochnoe Obozrenie = New Eastern Outlook, 2015, January 30. URL: https://ru.journal-neo.org/2015/01/30/iran-protivodejstviezapadny-m-sanktsiyam-v-bankovskoj-sfere/ (In Russ.)
} 
transferred to the other foreign bank on an account releasing it to Iran. Iran receives the amount in a currency it needs (U.S. dollars). In December 2012, there were announcements that Standard Chartered Bank managed to make more than 60 thousand transactions through the $U$-turn scheme for the Iranian financial institutions. The U.S. authorities then condemned the bank for money laundering for Iran. As a result, Standard Chartered Bank paid USD 327 million in penalties to the USA. Royal Bank of Scotland, UniCredit, HSBC, Deutsche Boerse, Société Générale and Crédit Agricole were also involved into the case, being accused of violation of the sanctions against Iran. Despite the U.S. sanctions, many renowned European banks continued the cooperation with the Iranian clients ${ }^{7}$.

Responding to the sanction in the above manner, the Iranian business sector managed to inhibit the economic slump and sustain business relations as active as possible in the given circumstances. However, in my opinion, the adverse effect of the Western restrictions could be mostly prevented. The Iranian business could have better tackled the banking restrictions, if the alternative interbank payment processing mechanism had been timely implemented with other things being equal.

There is a similar alternative in the Russian Federation nowadays, but it still has some limitations. This is the Central Bank of Russia's System for Transfer of Financial Messages (SPFS) running through the ICT system of the Central Bank of Russia and serving as an alternative interbank communication channel transmitting electronic messages about financial transactions in a steady and smooth manner. Russia's SPFS was launched at the end of 2014 after the European Parliament and foreign offices of the European countries warned about a possible exclusion of Russia from the SWIFT network. It is worth mentioning that the European Parliament called for such measures as part of the economic sanctions against Russia. However, the SWIFT network is formally independent from the EU and USA. According to its official statement, obeying this recommendation will tarnish its reputation and violate its right since the SWIFT remains a large and independent provider of

\footnotetext{
${ }^{7}$ Ibid.
}

financial services, without being bound by any political resolutions ${ }^{8}$.

The Russian analogue was designed to ensure the uninterrupted transfer of financial messages if the global service is banned. According to bank clerks, SPFS is not exposed to any external threats, thus being able to ensure the stability of the banking sector. As of December 1, 2017, 355 Russian banks were connected to SPFS. Hence, 46 percent of all credit institutions have already put SPFS into practice. Currently ministries elaborate how the BRICS nations could be linked to the Russian analogue of SWIFT ${ }^{9}$. However, the Russian product did have some flaws at the moment this article was written. Such flaws may include few financial and credit institutions connected to SPFS, insufficient presence in the international market, regulatory restrictions obstructing foreign entities to become clients of the Central Bank of Russia's SPFS, nonworking days and public holidays interrupting the SPFS operations. In my opinion, pros overwhelm contras since some conceptual aspects, such as zero fee for accession and servicing, lower messaging costs and ongoing system upgrade. These are important competitive advantages of the product in the international banking market. For the sake of comparison, SWIFT charges up to USD 200 thousand on each new customer connected to the network. The annual cost of service amounts to EUR 10 thousand ${ }^{10}$.

Trying to upgrade the Russian alternative payment processing network, the Central Bank of Russia intends to integrate blockchain technologies into the product. In this context it would be reasonable to describe the blockchain technology, summing up positive effects of its implementation in SPFS. Blockchain offers another method to store data or keep the digital ledger of transactions, deal and

\footnotetext{
${ }^{8}$ Belousov A.L. [Alternatives to the Society Worldwide Interbank Financial Telecommunications (SWIFT) for the Russian banking system]. Finany $i$ kredit = Finance and Credit, 2016, no. 16, pp. 19-26. URL: https://cyberleninka.ru/article/v/alternativy-mezhdunarodnoymezhbankovskoy-telekommunikatsionnoy-seti-swift-dlya-rossiyskoybankovskoy-sistemy (In Russ.)

${ }^{9}$ Tikhonov I. [SPFS vs SWIFT: Almost a half of the Russian banks adopted the homegrown financial messaging system]. Seichas.ru, 2016, January 16. URL: https://www.lawmix.ru/banki/3568 (In Russ.)

${ }^{10}$ SWIFT, SPFS and CyberFT. URL: https://cyberft.ru/about/comparison (In Russ.)
} 
contracts. They mainly constitute the information that shall be separately and independently recorded and verified, if needed. Blockchain may store details of granted loans, titles, breaches in road traffic rules, marriage registrations and any other sensitive information. What makes it so different and advantageous is that the ledger is not concentrated in one source but fragmented among several hundreds and even thousands of computers worldwide. In the technology, digital notes are aggregated into blocks, which are cryptographically and chronologically linked into a chain through complex mathematical algorithms. Each block is tied to the previous one, encompassing a set of records, while new blocks are inevitably added at the end of the chain. The encryption process, also known as hashing, is run by numerous computers connected to the same network. If their computations completely coincide, the block is assigned a unique digital signature. Once the ledger is updated and a new block is generated, it no longer can be altered, thus being unfalsifiable [11].

It should be noted that the ledger is renewed on all the computers of the network simultaneously. Therefore, the ramified nature of blockchain databases almost rules out the possibility of computer attacks because hackers would need to get access to databases of all the computers in the network. The blockchain technology also protects personal details of the sender, anonymizing the entire process. Even if the original document or transaction is modified in the future, they will be attached the other digital signature, signifying an instance of incompliance in the system [12]. Digital signatures serve for authorizing and modifying transactions since an intruder will not be able to make changes whatsoever without having a digital signature [13] (Fig. 2).

As for the hands-on usage of the blockchain technology, the financial sector may take the lead. The reason may be that blockchain-based transactions as part of financial services may significantly reduce costs and increase the efficiency of processes within a short period of time [14].

I believe that Central Bank of Russia's SPFS will be substantially improved and upgraded if it is fitted with the distributed ledger technology. The development and subsequent entry of the blockchain-based SPFS into the international market will not only secure transactions, protect personal details of communicating parties and streamline the exchange of information among clients, but also considerably reduce consumers' costs and handle transactions uninterruptedly 24/7. The tool will enable eligible banks to spend less resources and time on daily financial transactions, thereby optimizing their operations and circumvent international political and economic restrictions, like sanctions.

At the end of 2016, the Russian authorities resumed the digital economy development initiative. In his address to the Federal Assembly Russian President Vladimir Putin called for domestic advanced research and scientific solutions to move the economy and social sector forward. Vladimir Putin also emphasized the need to focus on the so called crosscutting technologies, i.e. digital technologies bringing the robust technological potential and shaping the overall picture of the economy. Furthermore, the Russian President suggested launching a largescale program for developing the economy of a new technological generation, which is to be created and implemented by the Russian corporations and research centers. Vladimir Putin also stressed the importance of the issue for the national security and technological independence of Russia [15]. In this respect, it is possible to say that the blockchain technology in SPFS revoices the mission of the digital economic development.

The Islamic Republic of Iran clearly demonstrated possible fallouts of economic sanctions. The EU and U.S. barriers to international financial flow of Iran turned to be very palpable for the economic situation there. As I mention above, an alternative international interbank payment system would reduce Iran's economic losses. The Russian payment system based on the blockchain technology would be primarily interesting for Iran since further sanctions against it are not improbable.

The blockchain-based SPFS is supposedly capable of morphing into a competitive and cost-effective product for financial institutions. Messages 
transmitted through the system will be processes at any time, without being trapped due to days-off and holidays because the technology will be unmanned.

Political background is not the last thing to mention in this context since global political and economic confrontations often induce restrictions and bans. The solution will back domestic banks in the case of such restrictions, facilitating their international financial transactions.

The EU countries may possibly become partners to cooperate and implement the Russian technology in the banking sector of a certain country [16]. According to experts, Iran considers the EAEU as a would-be strategic partner [17]. It may be a sign of possible economic cooperation between the EAEU countries and Iran, without using any Western payment mechanisms.

Currently, the Central Bank of Russia supervises and monitors the existing system of financial messaging on its own, thereby ensuring the security, stability and efficiency of its operations [18]. However, the role of the Central Bank of Russia should be revised in order to implement new technology into its SPFS from perspectives of its regulatory and supervisory functions since there is strong likelihood of illegal transactions, such as terrorism financing and money laundering. The Central Bank of Russia should also appoint a body to be responsible for security and protection of those who may use the payment system since they are exposed to hacking and other cyber threats [19].

Banking sanctions against Iran seriously affected its foreign trade relations. Iran revealed its dependence on the Western payment systems when the Iranian credit and financial institutions and companies were cut off from the SWIFT network. Pursuing the multipolarity of the world, it is sensible to consider not only geopolitical and military interests but also economic ones, especially in banking. Currently, SPFS operates in the Russian Federation as an alternative method for transacting. It is not widely spread since few users need to opt for the system and it has limited working hours.

If the Russian payment system is upgraded and fitted with the blockchain technology, it will unleash its potential and successfully enter the international market. The Russian alternative significantly reduces costs of financial institutions and decreases the dependence on the Western payment mechanisms. I believe, Iran is a priority for Russia's SPFS using the blockchain technology as its not only contributes to the cooperation of the nations in banking, but also bolsters the Russian-Iranian trade and economic relations and friendship.

\section{Figure 1}

Trends in the Gross Domestic Product of the Islamic Republic of Iran (2005-2015), billion USD

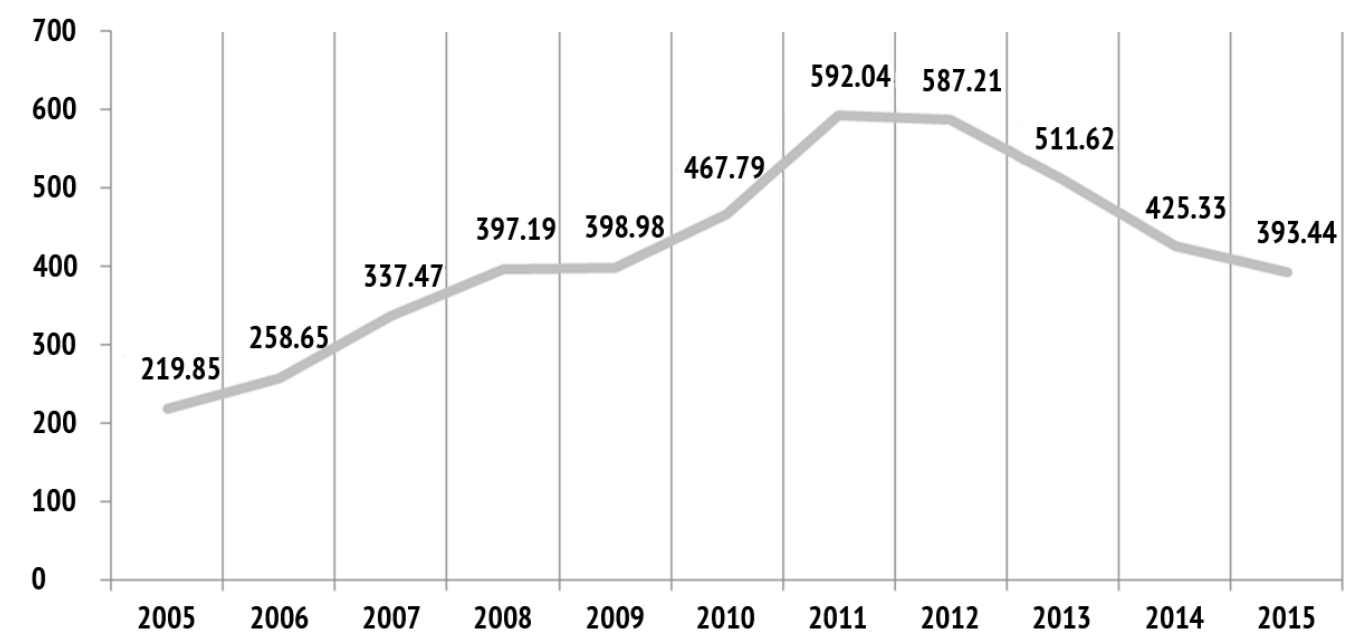

Source:The World Bank data 


\section{Figure 2}

Blockchain technology: An operation scheme
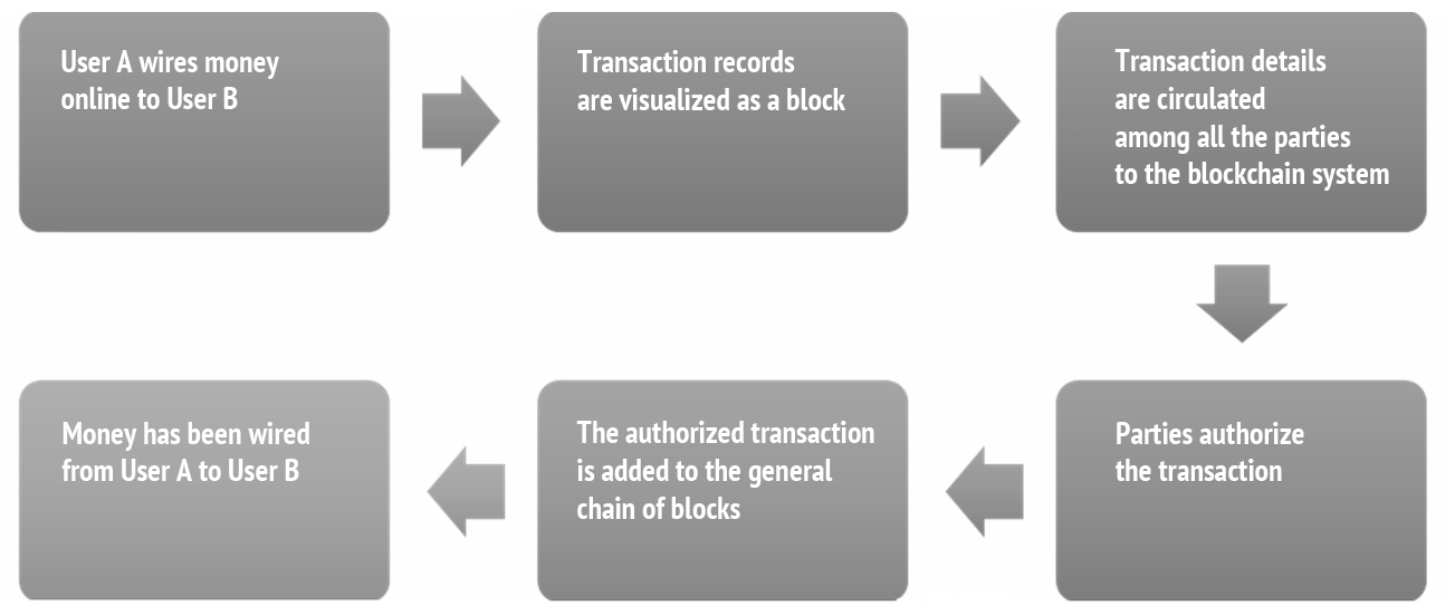

Source:Authoring based on materials published on URL: www.rocit.ru (In Russ.)

\section{References}

1. Sazhin V.I. [The Iran Nuclear Problem: Take-away from 2012]. Vestnik Moskovskogo universiteta. Seriya 25. Mezhdunarodnye otnosheniya i mirovaya politika = MSU Vestnik. Series 25. International Relations and World Politics, 2012, no. 4, pp. 70-96. (In Russ.)

2. Khazova E.V. [Legal regime for the national payment system in the Russian Federation: development perspectives]. Aktual'nye problemy rossiiskogo prava = Actual Problems of Russian Law, 2015, no. 8, pp. 71-77. (In Russ.)

3. Chernyshov A.S. [Worldwide interbank system SWIFT. Pros and Cons]. Molodoi uchenyi = Young Scientist, 2010, no. 1-2-1, pp. 266-270. (In Russ.)

4. Shkvarya L.V., Rusakovich V.I., Lebedeva D.V. [Russia-Iran: The development of cooperation in terms of sanctions]. Upravlenie ekonomicheskimi sistemami: elektronnyi nauchnyi zhurnal, 2014, no. 11, p. 43. (In Russ.) URL: http://uecs.ru/uecs71-712014/item/3174-2014-11-24-09-

5. Klepikov S.S. [Prospects of Russian-Iranian relations in the context of contemporary international situation]. Istoricheskaya i sotsial'no-obrazovatel'naya mysl' = Historical and Social-Educational Idea, 2017, vol. 9, no. 1-1, pp. 54-58. (In Russ.)

6. Tkachenko M.F., Bludova S.N. [Russia and Economic Challenges of the West]. Nauchno-analiticheskii zhurnal Obozrevatel' = Scientific-Analytical Journal Observer, 2015, no. 12, pp. 84-93. (In Russ.)

7. Salitskii A.I., Sin' Ch., Yurtaev V.I. [Sanctions and substitution of imports: Evidence from Iran and China]. Vestnik Rossiiskoi akademii nauk = Herald of the Russian Academy of Sciences, 2017, vol. 87, no. 3, pp. 263-271. (In Russ.)

8. Zernova L.E., Farzanian M. [Russia and Iran: Impact of Sanctions on the Banking System of the Country]. Innovatsionnaya nauka = Innovative Science, 2015, vol. 1, no. 1-2, pp. 127-131. (In Russ.)

9. Kolyushenko N.F. [Trade finance: Where will the ban on food imports into Russia lead?]. Mezhdunarodnye bankovskie operatsii = International Banking Operations, 2014, no. 3, pp. 16-21. (In Russ.) 
10. Glushchenko G.I. [Hawala - Vestige of Past at Service of Globalization]. Mirovaya ekonomika $i$ mezhdunarodnye otnosheniya $=$ World Economy and International Relations, 2004, no. 5, pp. 18-26. (In Russ.)

11. Chasovskikh V.P., Labunets V.G., Voronov M.P. [Blockchain technology (blockchain) in education of universities and the digital economy]. Eko-Potentsial, 2017, no. 2, pp. 99-105. (In Russ.)

12. Sukhanov E.E., Shtang K.S., Aleshko R.A. [The Blockchain Technology: Challenges, Constraints, Options for Improving]. Sinergiya nauk, 2017, no. 14, pp. 540-546. (In Russ.)

URL: http://synergy-journal.ru/archive/article0908

13. Babkin A.V., Burkal'tseva D.D., Pshenichnikov V.V., Tyulin A.S. [Cryptocurrency and blockchain technology in digital economy: development genesis]. Nauchno-tekhnicheskie vedomosti SPbGPU. Ekonomicheskie nauki $=$ Saint-Petersburg State Polytechnic University Journal. Economics, 2017, vol. 10, no. 5, pp. 9-22. (In Russ.)

14. Vladimirova L.V. [Perspectives of applying blockchain technology]. Fundamental'nye i prikladnye issledovaniya v sovremennom mire, 2017, no. 18-1, pp. 91-93. (In Russ.)

15. Pryanikov M.M., Chugunov A.V. [Blockchain as the Communication Basis for the Digital Economy Development: Advantages and Problems]. International Journal of Open Information Technologies, 2017, vol. 5, no. 6, pp. 49-55. (In Russ.)

16. Pil'shchikov Yu.S. [Financial relations of BRICS countries: Present state and prospects]. Regional'naya ekonomika i upravlenie: elektronnyi nauchnyi zhurnal, 2017, no. 1-3, pp. 454-467. (In Russ.) URL: http://eee-region.ru/article/4942/

17. Kozyrev N.I. [Iranian economy: Yesterday, today, tomorrow]. Vestnik diplomaticheskoi akademii MID Rossii, 2016, no. 2, pp. 129-147. (In Russ.)

18. Odnokoz V.G. [The role of the Central Bank in the payment system functioning in Russia]. Problemy ekonomiki i menedzhmenta = Problems of Economics and Management, 2014, no. 11, pp. 44-47. (In Russ.)

19. Kapustin F.A. [Information security and data protection in modern society]. Aktual'nye problemy aviatsii $i$ kosmonavtiki, 2016, vol. 2, no. 12, pp. 56-58. (In Russ.)

\section{Conflict-of-interest notification}

I, the author of this article, bindingly and explicitly declare of the partial and total lack of actual or potential conflict of interest with any other third party whatsoever, which may arise as a result of the publication of this article. This statement relates to the study, data collection and interpretation, writing and preparation of the article, and the decision to submit the manuscript for publication. 